\title{
Texting, Textisms and Teaching Portuguese
}

\author{
Alejandro Gómez-Camacho \\ Universidad de Sevilla \\ ANTÓNIO LOPES \\ Universidade do Algarve
}

Received: 08 May 2017 / Accepted: 25 June 2017

ISSN: $1697-7467$

\begin{abstract}
This study examines the perception of digital Portuguese spelling and its relationship to the teaching of Portuguese as L1 and L2. 85 undergraduate and graduate students in the fields of education and communication participated in the study through a 35 -item questionnaire, validated in both theoretical and the empirical terms. The qualitative analysis of the results showed a high rejection of the use of textisms at the graphic and phonological levels, which are regarded as being associated with standard Portuguese spelling mistakes. However, the multimodal elements of digital Portuguese were accepted as resources for the teaching of the language.
\end{abstract}

Keywords: texting, textisms, spelling, teaching of Portuguese.

\section{Mensajes de texto, textismos y enseñanza del portugués}

RESUMEN: Este estudio analiza la percepción de la norma del portugués digital y su relación con la enseñanza de la lengua portuguesa como L1 y L2. 85 estudiantes de grado de educación y comunicación participaron en el estudio a través de un cuestionario de 35 ítems, validado tanto en el plano teórico como en el empírico. El análisis cualitativo de los resultados mostró un elevado rechazo al uso de textismos del plano gráfico y fonológico que se asocian a errores ortográficos del portugués estándar. Sin embargo, los elementos multimodales del portugués digital se aceptaron como recursos para la enseñanza de esta lengua.

Palabras clave: mensajes de texto, textismos, ortografía, enseñanza del portugués.

\section{INTRODUCTION}

\subsection{The Portuguese language and ICT}

The Portuguese language has been acknowledged as one of the most important languages of international communication. Already back in 1989, the $25^{\text {th }}$ General Conference of the UNESCO claimed that it "is both a language belonging to many and varied civilizations and cultures and a medium of international communication whose importance in the world is growing, fostering dialogue and cooperation among the peoples and advancing the cause of peace." As a result, this organism of the UN agreed to pursue policies seeking "to promote the upgrading of Portuguese as a language used in the fields of science and technology, in particular through recourse to the new communication and information technologies" (UNESCO, 1989).

Portugal and Brazil have been making a joint effort to disseminate the language worldwide, and yet this has had little impact in terms of significantly increasing its presence on 
the Web. By the turn of the century, figures could hardly be said to be impressive. In fact, in September 1998 there were only 1.09 Web pages for every 100 in English, and in 2008 the percentage of pages in Portuguese corresponded to $1.65 \%$ of the total, in sharp contrast with $50.82 \%$ in English and $4.33 \%$ in Spanish (UNESCO, 2009). Data provided by https://w3techs.com on 22 June 2015 shows that that percentage rose to $2.5 \%$ (as opposed to $55.4 \%$ in English and $4.5 \%$ in Spanish) and now Portuguese ranks 8th. ${ }^{1}$

Still, these figures do not quite match the number of Portuguese-speaking users of the Internet. According to Internet World Stats, by December 2013, the number of users totaled $121,779,703(4.3 \%)$, with an impressive growth of $1,507.4 \%$ from 2000 to $2013 .{ }^{2}$ This means that the number of native speakers of Portuguese using the Internet is growing fast, but without any actual correspondence to the rather sluggish growth of Portuguese content online.

On the other hand, however, one cannot truly claim that Portuguese has remained untouched by the technological advances in the field of communication. In fact, ICT has brought a radical change in the way in which people communicate with each other, especially through writing. Short Message Service (SMS) messages and Microblogging services (such as Twitter, Tumblr, Google+ or Facebook Messenger) have been largely responsible for a new attitude towards writing. This is especially true of the younger generations, who have exploited the potential of these systems as the ubiquitous means of personal communication that can best meet the digital demands of our age.

Statistics show how fast this revolution took place. According to data provided by the Eurostat, the number of SMS messages produced in Portugal soared from little less than 20,000 million in 2007 to approximately 63,000 million two years later. In terms of average per inhabitant, it grew from little less than 300 messages a year in 2004 to 2,400 in 2009, way ahead of Germany, France and Spain. In the last trimester of 2014, each mobile phone user in Portugal was sending out an average of 261 messages a month, clearly surpassing the number of phone calls (180/month) (ANACOM, 2015). This corresponds, on average, to over 3,100 messages a year.

\subsection{The impact of texting on the language}

This has been the cause for some concern on the part of parents and educators. Until the beginning of the century, most of the children and teenagers' written production served, above all, educational purposes, and a great deal of what they wrote would be closely monitored by either the teacher or the parents. Since their assessment usually took the form of papers, written examinations, compositions, reports, etc. the students' writing behaviour was highly conditioned by the sanctioning power of the teacher. However, thanks to the fast spread of mobile devices and wireless networks their writing habits started to change over the years and so did the conventions and rules governing writing in these other media.

One can argue that, up to a certain point, the research that has been conducted into the dangers that these new spaces of freedom of expression may pose to the officially sanctioned forms of writing derives from the educators' sense of powerlessness and of loss of control over the learners' writing process. Creativity and the new conventions governing

\footnotetext{
${ }^{1}$ http://w3techs.com/technologies/history_overview/content_language/ms/y

${ }^{2} \mathrm{http}: / /$ www.internetworldstats.com/stats $7 . \mathrm{htm}$
} 
texting appear to challenge spelling and grammar rules, and empirically teachers are prone to conclude that the risk of compromising the alleged purity of the language is real (Freitas, 2008; Mosqueira-Castro, 2010; Geertsema et al., 2011).

This is not to say that the results of recent research corroborate the ideas that have fostered prejudice against texting and textisms (or its correlates, such as the "Internetese"). Quite the opposite: several studies conducted in the United States (Drouin and Driver, 2014; Gann et al., 2010), England (De Jonge y Kemp, 2012; Plester et al. 2008), France (Bernicot et al., 2014), Spain (Gómez-Camacho, 2007 and 2014; Vázquez-Cano et al., 2015), and Brazil (Silva, 2014; Freitas, 2010), just to mention a few, have shown that the use of textisms cannot be related to low literacy performance. What is more: in some studies, the learners have evidenced an improvement in literacy skills, especially spelling (Wood et al., 2011; Grace and Kemp, 2015).

\subsection{Possible reasons for (unfounded) suspicion}

These results notwithstanding, the prejudicial views about the alleged interference of these ICT-mediated writing practices in the quality of the Portuguese language are shared not only by the educators and parents, but also by the students themselves. Komesu shows that university students in Brazil are very critical of the people who make use of these new forms of writing, arguing that they either do not know how to express themselves, are semiilliterate or, worse still, suffer from mental disorders. On the other hand, the students believe that the ability to express oneself according to standard Portuguese - the legitimate bearer of national identity - is the only way to prove that one can actually master the complexity of thought (2006: 435).

In Portugal, the suspicion about the interference of ICT in language, along with the fear of it irremediably corrupting the language, has been further aggravated by the polemics on the official adoption of the 1990 Spelling Reform, aimed to standardize spelling in Portuguesespeaking countries. The debate raged in Portuguese society for almost two decades before the accord was finally passed in parliament in 2008. Instead of bringing a stop to the discussion, the parliament's decision has widened the chasm between groups of linguists, intellectuals, educators and several other stakeholders. Many regard the accord as "a political instrument for the expansion of Brazil" (Cabral, 2010). José Pacheco Pereira, a leading intellectual and historian, goes further in his criticism, stating that the accord is not only damaging to the language, but also detrimental to the cultural identity of the Portuguese (2015).

Other causes to explain this suspicion can be hypothesized, but not proved. Nevertheless, if people in the field of education still harbour some doubts over the impact of ICT on spelling and on the language itself, then one should attempt to gauge their perceptions of texting and of textisms, since their attitudes in this respect will always bear some relation to the teaching and learning of the language itself, be it as L1 or L2.

Hence the importance of conducting a survey with university students in the areas of education and communication. As future teachers and media professionals, their views can either help to dispel such misconceptions, or simply keep on perpetuating stereotypes and preconceived judgments.

If the teacher is willing to take on language teaching approaches that come closer to the real use of language, then he cannot forsake the forms of written production that have 
become predominant amongst the youngsters. It comes as no surprise that researchers have already started delving into the potential of these ICT-mediated writing practices in the leveraging language teaching and learning processes (see, for example, Vosloo, 2011).

A number of studies have sought to establish the taxonomy of textisms in digital communication in the languages that bear some relation to the Portuguese. In the context of the English language, Plester et al. (2009), de Jonge and Kemp (2012), Lyddy et al. (2014), and Wood et al. (2014) offer a full account of the differential traits of writing in text messages. The same can be said of the French language, in particular the studies conducted by Bouillaud et al. (2007) and Bernicot et al. (2014). As far as the Spanish language is concerned, the proposals made by Gómez-Camacho and Gómez (2015) and Vázquez-Mengual et al. (2015) are also quite revealing. In this study, we propose a classification of textisms in Portuguese language in table 1.

Table 1. Category of non-standard spelling in Portuguese

\begin{tabular}{|c|c|c|}
\hline Textisms & Keys & Examples \\
\hline $\begin{array}{l}\text { The use of abbreviations and acro- } \\
\text { nyms }\end{array}$ & $A b b A c r$ & $\begin{array}{c}\text { TB (tudo bem) [everything's OK]; SQN (Só } \\
\text { que não) [It's just that it won't (do)]; FDS } \\
\text { (fim de semana) [weekend] +/-(mais ou } \\
\text { menos) [more or less]; + trd (mais tarde) } \\
\text { [later]; = mente (igualmente) [likewise]; } \\
\text { = (igual) [the same]; 1 mnt (um minuto) } \\
\text { [one minute]; Immt (um momento) [one } \\
\text { momento]; } 2 \text { (tu) [you]; \$ (dinheiro; massa) } \\
\text { [money; cash] }\end{array}$ \\
\hline Replacement of letters with numbers & Numb & $\begin{array}{l}7 \text { d (semana) [week]; 6nema (cinema) [cine- } \\
\text { ma]; 4te dps (até depois) [See you later]. }\end{array}$ \\
\hline $\begin{array}{l}\text { Replacement of the fricatives } s, s s \text {, } \\
\text { ch, } c \text { and ç with } x\end{array}$ & NonstSpellx & $\begin{array}{c}\text { "To xim..." (Estou sim...) [Hello there or Yes } \\
\text { I am] }\end{array}$ \\
\hline $\begin{array}{l}\text { Replacement of the occlusive conso- } \\
\text { nants } \mathrm{c} \text { and } \mathrm{q} \text { with } \mathrm{k}\end{array}$ & NonstSpellk & $\begin{array}{c}\text { kfzes? (Que fazes?) [What are you doing?] } \\
\text { Kres dar o EM * e o TLM?(Queres dar o } \\
\text { e-mail e o [número de] telemóvel?) [Do you } \\
\text { want to give me your e-mail and phone num- } \\
\text { ber?] }\end{array}$ \\
\hline Omission of graphic accents & AccOmi & $\begin{array}{c}\text { Kres tmr } 1 \text { kafe? (Queres ir tomar um café?) } \\
\text { [Would you like to have some coffee?] }\end{array}$ \\
\hline Omission of capital letters & CapOmi & $\begin{array}{c}\text { fui a faro e } n \text { vi o pedro (fui a faro e não vi } \\
\text { o pedro) [I went to Faro and I didn't meet } \\
\text { Pedro] }\end{array}$ \\
\hline Vowel reduction/elision & ShortVoc & tenh $d$ ver iss (Tenho de ver isso) \\
\hline
\end{tabular}




\begin{tabular}{|c|c|c|}
\hline Omission of connectors and articles & OmiCon & $\begin{array}{c}\text { João saiu [e] eu fiquei em casa. [João went } \\
\text { out (and) I stayed home]; Vais sair [ou] } \\
\text { ficas? [Staying (or) going out?]; 'É Natal, } \\
\text { [mas] estou triste." [It's Christmas, [but] I'm } \\
\text { sad.] }\end{array}$ \\
\hline $\begin{array}{l}\text { Emoticons with punctuation marks } \\
\text { and special characters }\end{array}$ & Emo & $\left.\left.\left(\wedge_{-} \wedge\right)(B-)\left(\wedge_{-} \wedge_{;}\right):-\right)\right)$ \\
\hline Multimedia elements & Mult & audios; videos; images. \\
\hline
\end{tabular}

\section{2. Мethod}

The study employs a non-experimental design of a descriptive type based on polls (survey). Given its temporal dimension and the fact that the data were collected in one single moment, the design underlying this approach is trans-sectional.

\subsection{Objectives}

The study focused on the knowing how the Portuguese university students perceive the writing rules used in the text messages in mobile communication, how those rules are related to the official Portuguese spelling rules and how the latter are learnt in the context of secondary education.

The study addressed the following research questions: 1) Do the participants in the study perceive textisms in a negative way?; 2) Can they identify the differences between the features that characterize the writing of digital Portuguese?; 3) Do they consider that these features exert a negative influence on the orthography of the young students who are learning Portuguese either as L1 or as L2?

\subsection{Sample}

The study is based on an analysis of the responses of 85 Portuguese university students to a questionnaire. These students attended the School of Education and Communication, University of Algarve (Portugal).

\subsection{Instrument}

A questionnaire entitled "A grafia dos SMS em Língua Portuguesa" ["The SMS spelling in Portuguese"] was designed. It comprised 35 items (31 items scored on a five-point Likert scale, where $1=$ strongly disagree/never and $5=$ strongly agree/always). The questionnaire is based on three a priori dimensions that address the perception of textisms used in Portuguese from three points of view. Dimension 1 examines the participants' perception of their own spelling skills in formal texts written in Portuguese, which is presumed to be very positive in university students. Dimension 2 deals with the relationship between spelling mistakes and textisms. Students were asked whether the textisms identified in table 1 were spelling 
mistakes in text messages written in Portuguese. Finally, Dimension 3 focuses on the educational implications of the use of textisms, and students were questioned about whether these textisms lead to errors in formal texts written by students in compulsory education. The data were exported from a Google Form to an Excel spreadsheet and later subjected to a factorial analysis of variance using the SPSS 19.0 programme.

The validity of the instrument used was established both at a theoretical and an empirical level. As regards the theoretical validity, an initial version of this questionnaire was presented to a group of 10 teachers and researchers at the Universities of Seville and Algarve. These teachers evaluated the instrument and made recommendations to improve the wording of the items.

The construct validity of the instrument has been determined by the two subscales that compose it, namely: a) the use of textisms and its perception as misspelling; and b) the educational impact of the use of textisms. The results of the KMO test (.824 and .852) and Bartlett's test of sphericity $(p=.000)$ in both scales show the importance of performing an exploratory factor analysis using the maximum likelihood. After the application of this test, and taking as criteria, on the one hand, eigenvalues above 1, and, on the other, the fact that the final structure should bear a logical correspondence to its explanation, the variables have been grouped in 2 factors (textisms and multimodal elements), with an explanatory power of $60.94 \%$ variance for the first scale and $60.60 \%$ for the second one.

As far as reliability is concerned, taking as a reference the criteria of George and Mallery (2003), it may be considered, good in some cases, as Cronbach's alpha values between .84 and .86 for each of the dimensions have been reached (see table 2).

Table 2. Psychometrics of the measuring instrument

\begin{tabular}{|c|c|c|c|}
\hline Factors & Keys & $\begin{array}{c}\text { Reliability } \\
\text { (D2) }\end{array}$ & $\begin{array}{c}\text { Reliability } \\
\text { (D3) }\end{array}$ \\
\hline 1 & Multimodal elements & .88 & .85 \\
\hline 2 & Textisms & .85 & .88 \\
\hline Total & & .84 & .86 \\
\hline
\end{tabular}

\section{Data Analysis and Results}

\subsection{Perception of textisms}

Table 3 is a summary of the main descriptive statistical data obtained in each of the three dimensions of study. The first one includes two categories of analysis, and refers to the use that the respondents make of the spelling rules of the Portuguese language and the perception of the application of these same rules regarding the writing of text messages using messaging applications. Concerning Dimension 1, the respondents show that in general they have a very positive perception of their own spelling skills in Portuguese (Accent marks, 
$\dot{\mathrm{x}}=4.28$; Punctuation marks, $\dot{\mathrm{x}}=4.30$; Uppercase, $\dot{\mathrm{x}}=4.28$; Correct choice of letters, $\dot{\mathrm{x}}=$ 4.08). As for the second category, they state that they use textisms in a moderate way in the writing of text messages in messaging applications (Textisms, $\dot{x}=2.63$ ), despite the fact that it may be seen as a deliberate discrepancy with regard to standard Portuguese spelling (Digital Portuguese spelling, $\dot{\mathrm{x}}=3.40$ ).

Dimension 2 is focused on the use of textisms in the text messages written by the participants in the study. It refers more precisely to the relationship between textisms and its consideration as misspellings, and shows that, for the 11 variables studied within the dimension, there is a common perception among the participants surveyed that the different types of textisms that may appear are generally regarded as misspellings. In this sense, the rejection of textisms is very clear when they are associated with the typical Portuguese spelling errors, such as vowel reduction/elision (ShortVoc, $\dot{\mathrm{x}}=4.17$ ), the replacement of $s$, ss, $c h, c$ and $c$ with $x$ (NonstSpellx, $\dot{\mathrm{x}}=4.64$ ), the replacement $c$ and $q$ with $k$ (NonstSpellk, $\dot{\mathrm{x}}=4.37$ ), or the omission of accent marks (AccOmi, $\dot{\mathrm{x}}=4.28$ ).

Conversely, textisms not associated with spelling errors caused by lack of knowledge are less rejected both at the normative and the educational levels, such as, for example, the use of acronyms (Acr, $\dot{\mathrm{x}}=2.62)$, letter/number homophones (Numb, $\dot{\mathrm{x}}=3.90)$ or omission of articles and connectors (OmiCon, $\dot{\mathrm{x}}=3.71$ ).

As a distinctive case, but in line with the above, the incorporation of emoticons and multimodal elements (such as images, audios and videos) in text messages is perceived as an element that threatens neither the spelling rules of Portuguese nor the education of teenage students (Mult, $\dot{\mathrm{x}}=1.41$ and Emo, $\dot{\mathrm{x}}=1.61$ ).

In relation to Dimension 3, which addresses the impact that textisms are believed to have on education, there is a common perception among the participants in the study that the use of different types of textisms can cause spelling mistakes in the formal texts that students produce. The parallelism between the normative and the pedagogical dimensions is striking. Textisms associated with the typical spelling errors in Portuguese are, for example, vowel reduction/elision (ShortVoc, $\dot{\mathrm{x}}=4.17$ ), the replacement of $s, s s, c h, c$ and $c$ with $x$ (NonstSpellx, $\dot{\mathrm{x}}=4.56$ ), the replacement of $c$ and $q$ with $k$ (NonstSpellk, $\dot{\mathrm{x}}=4.36$ ), and the omission of accent marks (AccOmi, $\dot{\mathrm{x}}=4.37$ ). As expected, the textisms not associated with spelling errors are less rejected at the educational level such as, for example, the use of acronyms (Acr, $\dot{\mathrm{x}}=3.72$ ), the letter/number homophones (Numb, $\dot{\mathrm{x}}=3.79$ ) or omission of articles and connectors (OmiCon, $\dot{\mathrm{x}}=3.83$ ).

The participants in the study almost unanimously considered that teachers of Portuguese should correct the use of textisms in digital communication (Tea, $\dot{x}=4.15$ ), and that the use of textisms that follow the digital Portuguese standard is harmful both for the Portuguese language (D2 TexUse, $\dot{\mathrm{x}}=4.15$ ), as well as for the academic literacy of teenagers in secondary education (D3 TexUse, $\dot{\mathrm{x}}=4.33$ ). However, there is a moderate correlation between the recognition of digital Portuguese as a deliberate discrepancy in relation to standard Portuguese (DigNorm) and the use of textisms in Dimensions 2 and 3 (D2 TexUser $=-.238$, $\rho<.05$; D3 TexUse $r=-.243, \rho<.05$ ), which suggests that those participants who recognize digital Portuguese as an acceptable standard in text messages have a greater tolerance for textisms both in the digital standard and in the educational context. 
Table 3. Descriptive statistical data referred to variables of Dimensions 1, 2 and 3.

\begin{tabular}{|c|c|c|c|c|}
\hline & $\begin{array}{c}\text { Dimension 1 } \\
\text { (Standard } \\
\text { Portuguese) }\end{array}$ & Textism & $\begin{array}{c}\text { Dimension 2 } \\
\text { (Digital Portuguese) }\end{array}$ & $\begin{array}{c}\text { Dimension 3 } \\
\text { (Teaching of Portuguese) }\end{array}$ \\
Acc & 4.28 & TexUse & 4.20 & $\dot{\mathrm{x}}$ \\
Pun & 4.30 & ACR & 2.62 & 4.33 \\
Cap & 4.28 & Numb & 3.90 & 3.72 \\
Ort & 4.08 & NonstSpellx & 4.64 & 3.79 \\
TextUse & 2.63 & NonstSpellk & 4.37 & 4.56 \\
DigNorm & 3.40 & AccOmi & 4.28 & 4.36 \\
& & CapOmi & 3.71 & 4.37 \\
& & ShortVoc & 4.17 & 3.70 \\
& & OmiCon & 3.71 & 4.17 \\
& & Emo & 1.61 & 3.83 \\
& & Mult & 1.41 & 1.69 \\
\hline
\end{tabular}

Key: see Table 1, Acc: standard accentuation, Pun: standard punctuation, Cap: use of standard uppercase, Ort: standard use of graphemes, TextUse: use of textisms, DigNorm: digital Portuguese standard.

\subsection{Correlations between textisms}

At a correlational level, we used the Pearson correlation coefficient test to address possible relationships between the variables studied for Dimensions 2 and 3. Levels of statistical significance of $\rho<.05$ and $\rho<.01$ were established. The results of the study of correlations are shown in tables 4 and 5.

\subsubsection{Textisms and spelling mistakes}

In relation to Dimension 2 and its variables related to the possible association between textisms and spelling mistakes, significant correlations in most of the variables were detected (see table 4). As a result, participants in the study share the common perception that the majority of the textisms analysed are considered to be spelling mistakes. This idea underscores what was previously said when the main descriptive statistics of Dimension 2 were discussed.

At the level of the textisms associated with spelling mistakes in standard Portuguese, strong positive correlations were found between the non-normative writing of graphemes $x$ 
and $k$ (NonstSpellx - NonstSpellk, $r=.735, \rho<.01$ ). In turn, these two textisms are strongly correlated with the omission of accent marks $(r=.573, \rho<.01 ; r=.581, \rho<.01)$ and with vowel reduction/elision $(r=.659, \rho<.01 ; r=.699, \rho<.01)$. The omission of accent marks and vowel reduction/elision also show a very significant correlation $(r=.609, \rho<.01)$.

No less significant is the use of multimodal elements (Mult) and emoticons (Emo), which show the lowest correlations with the textisms considered as spelling mistakes. On the other hand, they are correlated among themselves with the highest value reached in the dimension of the digital Portuguese standard (Emo - Mult, $r=.803, \rho<.01$ ).

Table 4. Correlation matrix representing Pearson's $r$ between variables for Dimension 2"Digital Portuguese"

$$
(N=87, * \mathrm{p}<.05, * * \mathrm{p}<.01) .
$$

\begin{tabular}{|c|c|c|c|c|c|c|c|c|c|c|}
\hline & 1 & 2 & 3 & 4 & 5 & 6 & 7 & 8 & 9 & 10 \\
\hline \multicolumn{11}{|l|}{1 TexUse } \\
\hline 2 Acr & .182 & & & & & & & & & \\
\hline $3 \mathrm{Numb}$ & $.244 *$ & .124 & & & & & & & & \\
\hline 4 NonstSpellx & $.479 * *$ & .209 & $.533 * *$ & & & & & & & \\
\hline 5 NonstSpellk & $.396 * *$ & $.291 * *$ & $.506 * *$ & $.735 * *$ & & & & & & \\
\hline 6 AccOmi & $.370 * *$ & .121 & $.467 * *$ & $.573 * *$ & $.581 * *$ & & & & & \\
\hline 7 CapOmi & $.438 * *$ & $.367 * *$ & $.455 * *$ & $.509 * *$ & $.405 * *$ & $.497 * *$ & & & & \\
\hline 8 ShortVoc & $.459 * *$ & $.293 * *$ & $.580 * *$ & $.659 * *$ & $.699 * *$ & $.609 * *$ & $.449 * *$ & & & \\
\hline 9 OmiCon & $.246^{*}$ & $.382 * *$ & $.332 * *$ & $.340 * *$ & $.400 * *$ & $.339 * *$ & $.217 *$ & $.508 * *$ & & \\
\hline 10 Emo & -.027 & $.509 * *$ & .117 & .111 & .134 & .208 & $.267 *$ & .148 & $.240 *$ & \\
\hline 11 Mult & -.041 & $.471 * *$ & .133 & .035 & .083 & .116 & $.241 *$ & .097 & .188 & $.803 * *$ \\
\hline
\end{tabular}

\subsubsection{Textisms and educational impact}

In relation to Dimension 3 and its variables, related to the impact that textisms have on the educational context, we note the existence, with different levels of significance, of positive correlations in a large number of variables (see table 4). That is, the participants considered that the use of textisms by students is responsible for spelling mistakes in the formal texts that they produce. This idea is consistent with what was previously said when the main descriptive statistics of Dimension 3 were discussed. 
In terms of the levels of correlation between the variables of the above-mentioned dimension, the textisms that were analysed show higher values than those included in the previous table of correlations of variables of Dimension 2. This implies that the participants, though believing that textisms are spelling mistakes, are even more convinced that textisms cause spelling mistakes in the formal texts produced by teenage students.

The results from the classification of the textisms analyzed show a high correlation between the four textisms associated with spelling mistakes that we have already described in the previous dimension, between $r=.759, \rho<.01$, of the non-normative use of $x$ and the omission of accent marks, and $r=.540, \rho<.01$, (NonstSpellx - ShortVoc).

Finally, emoticons, pictures, audios or videos are considered to be less influential in the production of mistakes in formal texts, which is confirmed by the low correlation reached with the rest of possible textisms collected in the variables of this Dimension (Emo and Mult $\rho$ between, $240 *$ and $404 *$ ). As in dimension 2, the use of emoticons and multimodal elements shows the most significant correlation in the pedagogical dimension of the digital standard (Emo - Mult, $r=.765, \rho<.01$ ).

Table 5. Matrix representing Pearson>s correlation $r$ between variables for Dimension 3. "Teaching Portuguese"

$(\mathrm{N}=87, * \mathrm{p}<.05, * * \mathrm{p}<.01)$.

\begin{tabular}{|l|l|l|l|l|l|l|l|l|l|l|}
\hline & 1 & 2 & 3 & 4 & 5 & 6 & 7 & 8 & 9 & 10 \\
\hline 1 TexUse & & & & & & & & & & \\
\hline $2 \mathrm{Acr}$ & $.403 * *$ & & & & & & & & & \\
\hline $3 \mathrm{Numb}$ & $.485 * *$ & $.387 * *$ & & & & & & & & \\
\hline 4 NonstSpellx & $.789 * *$ & $.357 * *$ & $.461 * *$ & & & & & & & \\
\hline 5 NonstSpellk & $.565 * *$ & $.378 * *$ & $.462 * *$ & $.701 * *$ & & & & & & \\
\hline 6 AccOmi & $.623 * *$ & $.402 * *$ & $.472 * *$ & $.759 * * .669 * *$ & & & & & \\
\hline 7 CapOmi & $.471 * *$ & $.371 * *$ & $.300 * *$ & $.448 * *$ & $.462 * *$ & $.484 * *$ & & & & \\
\hline 8 ShortVoc & $.539 * *$ & $.572 * *$ & $.457 * *$ & $.540 * *$ & $.561 * *$ & $.565 * *$ & $.585 * *$ & & & \\
\hline 9 OmiCon & $.389 * *$ & $.401 * *$ & $.558 * * .356 * *$ & $.383 * *$ & $.449 * *$ & $.407 * *$ & $.468 * *$ & & \\
\hline 10 Emo & .160 & $.404 * *$ & .207 & .011 & .138 & .069 & .147 & .173 & $.240 *$ & \\
\hline 11 Mult & .064 & $.302 * *$ & .109 & -.064 & .045 & .008 & .077 & .098 & .181 & $.765 * *$ \\
\hline
\end{tabular}




\section{Discussion and Conclusion}

The analysis of the data on the perception of the rules used in text messages in Portuguese and its relationship with the writing of teenagers who are learning Portuguese either as L1 or as L2 allows conclusions to be drawn with a remarkable significance.

The results clearly show that those future teachers and communicators in Portuguese who participated in the study frequently communicate via instant messaging applications using their smartphones connected to the Internet. To write these texts, they make use of a digital standard that intentionally does not abide by standard Portuguese spelling, although they do so less frequently than people in the other languages that bear some relation to the Portuguese, namely the English, the French or the Spanish.

The fact that these speakers make use of what we may call "digital Portuguese" in their text messages does not prevent them from showing a high rejection of the use of textisms in text messaging. This is so because they identify them as a threat to standard Portuguese writing rules, although the younger participants and those who make more use of textisms in their text messages are more tolerant of the new digital standard, both in the context of the digital communication in Portuguese and in the educational context of the teaching of Portuguese.

Secondly, there is a clear difference between textisms associated with spelling mistakes and those associated with digital Portuguese. Textisms such as vowel reduction/elision, the non-normative use of $x$ and $k$, or the omission of accent marks are identified as spelling mistakes in standard Portuguese and have an extremely high rejection both in the context of the teaching of Portuguese and in mobile communication. On the other hand, textisms not associated with spelling mistakes such as the use of acronyms, letter/number homophones, or the omission of articles and connectors are more readily accepted in digital Portuguese and in the context of formal education. In conclusion, it is not appropriate to talk about textisms in general in digital Portuguese, as there is a clear distinction between the textisms affecting the phonetic and phonological domains - particularly in the relationship between phonemes and graphemes - , and those which operate at the lexical-semantic level. These data match the results of Bernicot et al. (2014) for the French language and Gómez-Camacho \& Gómez (2015) for the Spanish language. In addition, this differentiation between the phonetic and phonological level and the lexical-semantic level is also observed in the different ways the participants in the study regard the normative linguistic dimension, on the one hand, and the educational pedagogical dimension, on the other. This could be explained by the fact that textisms that alter the traditional relationship between graphemes and phonemes in Portuguese match the spelling mistakes in formal texts, which are typical of speakers with poor writing skills.

Thirdly, the use of multimodal elements such as emoticons, pictures, audios and videos, which do not exist in standard Portuguese writing, are identified as characteristics of digital Portuguese and have high acceptance rates both in text messages and in the educational context. Multimodality would therefore be the feature of the text messages that the participants in the study identify with a teaching resource suitable for the teaching of Portuguese - either as a language of schooling or as foreign language - to teenage students, as opposed to other textisms associated with standard Portuguese spelling mistakes. 
A speculative explanation for the high rejection of the use of textisms as a teaching resource for the teaching of Portuguese and as a writing resource in digital Portuguesemuch higher than in the languages that bear some relation to the Portuguese-could lie in the controversy over the recent reform of Portuguese spelling, which could have prompted the defense of former spelling rules. This hypothesis is strengthened by the fact that the participants in the study were European students in the field of education and communication in Portuguese language.

\section{REFERENCES}

ANACOM (2015). Factos \& Números - 1. ${ }^{\circ}$ trimestre 2015, available from http://www.anacom. pt/streaming/Factos_e_Numeros_1T15.pdf?contentId=1359509\&field=ATTACHED_FILE, accessed 20 June, 2016.

Bernicot, J., Goumi, A., Bert-Erboul, A. and Volckaert-Legrier, O. (2014). "How do skilled and less-skilled spellers write text messages? A longitudinal study", in Journal of Computer Assisted Learning, 30: 559-576.

Bouillaud, C., Chanquoy, L. and Gombert, J. (2007). "Cyberlangage et orthographe: Quels effets sur le niveau orthographique des élèves de CM2, 5e et $3 \mathrm{e}$ ?", Bulletin de Psychologie, 492: 553-565.

Cabral, T. (2010). Spelling reform causes Portuguese headaches, in The Telegraph, 1 March 2010.

De Jonge, S. and Kemp, N. (2012). "Text-message abbreviations and language skills in high school and university students", in Journal of Research in Reading, 35, 1: 49-68.

Drouin, M. (2011). "College students' text messaging, use of textese and literacy skills", in Journal of Computer Assisted Learning, 27: 67-75.

Drouin, M. and Driver, B. (2014). "Texting, textese and literacy abilities: a naturalistic study", in Journal of Research in Reading, 37, 3: 250-267.

Freitas, H. S. (2008). "Grafia alterada utilizada por adolescentes pode comprometer futuro da Língua Portuguesa", in RTP Noticias, 30 de julho de 2008, available from http://www. rtp.pt/noticias/pais/grafia-alterada-utilizada-por-adolescentes-pode-comprometer-futuro-dalingua-portuguesa_n64074, accessed 16 June, 2016.

Freitas, L. (2010). "Preconceito Linguístico em rede: uma análise discursiva das representações do Internetês em comunidades do Orkut", in Linguagens e Diálogos, 1, 2: 106-120.

Gann, R., Bartoszuk, K. and Anderson, J. (2010). "If u txt 2 much, duz it mean u cant spell: Exploring the Connection between SMS Use and Lowered Performance in Spelling", in The International Journal of the Book, 7, 2, available from: http://www.Book-Journal. com, accessed 11 June 2016.

Geertsema, S., Hyman, C. and Van Deventer, C. (2011). "Short message service (SMS) language and written language skills: educators' perspectives," in South African Journal of Education, 31: 475-487.

George, D. And Mallery, P. (2003), SPSS for Windows Step by Step: A Simple Guide and Reference (11.0 update), Boston: Allyn \& Bacon.

Gómez-Camacho, A. (2007). "La ortografía del español and los géneros electrónicos en la educación secundaria", in Comunicar, 29: 157-164.

Gómez-Camacho, A. (2014). "La norma disortográfica en la escritura digital", in Didac, 63: 19-25.

Gómez-Camacho, A. and Gómez, M. (2015). "Escritura ortografica y mensajes de texto en estudiantes universitarios", in Perfiles Educativos, 150: 91-104. 
Grace, A. and Kemp, N. (2015). "Assessing the Written Language of Text Messages", in Rosen, L.; Cheever, N. and Carrier, L.M. (eds.), The Wiley Handbook of Psychology, Technology, and Society, Chichester: John Wiley \& Sons: 207-231.

Komesu, F. (2006). "Visões da língua(gem) em comentários sobre Internetês não é Língua Portuguesa", in Revista Filologia e Linguística Portuguesa, 8: 425-437.

Lyddy, F., Farina, F., Hanney, J., Farrell, L. and O’Neill, N. (2014), “An Analysis of Language in University Students' Text Messages", in Journal of Computer-Mediated Communication, 19, 3: 546-561.

Mosqueira-Castro, E. (2013), "A escrita SMS desde a perspectiva dos seus utentes.Unha achega sobre a lingua galega", in Madrygal, 16: 63-71.

Pereira, J. (2015), "Os apátridas da língua que nos governam”, in Público, 16 de maio 2015.

Plester, B., Wood, C. and Bell, V. (2008). "Txt Msg n school literacy: Does mobile phone use adversely affect children's literacy attainment?", in Literacy, 42: 137-144.

Plester, B., Wood, C. and Joshi, P. (2009). "Exploring the relationship between children's knowledge of text message abbreviations and school literacy outcomes", in British Journal of Developmental Psychology, 27: 145-161.

Silva, A. (2014), "As implicações do internetês na ortografia: um estudo em duas escolas públicas paulistas", in Revista Letras Raras, 4, 1: 93-107.

UNESCO (1989). Records of the General Conference, Twenty-fifth Session. Paris: UNESCO.

UNESCO (2009). Twelve years of measuring linguistic diversity in the Internet: balance and perspectives. Paris: UNESCO.

Vázquez-Cano, E., Mengual-Andrés, S. and Roig-Vila, R. (2015). "Análisis lexicométrico de la especificidad de la escritura digital del adolescente en WhatsApp", in Revista de Lingüistica Teórica and Aplicada, 53, 1: 83-105.

Vosloo, Steve (2009). "The effects of texting on literacy: Modern scourge or opportunity?", Shuttleworth Foundation issue paper, April, available from: http://citeseerx.ist.psu.edu/viewdoc/ download?doi=10.1.1.468.1595\&rep=rep1\&type=pdf, accessed 16 June 2016.

Wood, C., Jackson, E., Hart, L.; Plester, B. and Wilde, L. (2011). "The effect of text messaging on 9- and10-year-old children's reading, spelling and phonological processing", in Journal of Computer Assisted Learning, 27: 28-36.

Wood, C., Kemp, N., Waldron, S. and Hart, L. (2014). "Grammatical understanding, literacy and text messaging in school children and undergraduate students: a concurrent analysis", in Computers \& Education, 70: 281-290. 